\title{
PEMANFAATAN PANAS GAS BUANG SEPEDA MOTOR SEBAGAI SUMBER ENERGI ALTERNATIF MENGGUNAKAN TEKNOLOGI THERMOELEKTRIK
}

\author{
Ragil Sukarno \\ Jurusan Teknik Mesin, Fakultas Teknik - Universitas Negeri Jakarta \\ Email : ragil-sukarno@unj.ac.id
}

\begin{abstract}
Abstrak
Seiring peningkatan penggunaan kendaraan bermotor, secara tidak langsung berdampak pada peningkatan energi panas buang yang dibuang melalui knalpot. Penelitian ini bertujuan untuk menghasilkan sebuah konstruksi thermoelectrik generator (TEG) yang bisa mengkonversi energi dari panas gas buang knalpot sepeda motor menjadi energi listrik dan melihat seberapa besar energi listrik yang bisa dibangkitkan pada variasi kecepatan putaran mesin. Konstruksi TEG terdiri dari alat penukar kalor sisi panas yang berupa komponen setengah lingakaran yang mengikat pada dinding knalpot dan sebuah plat datar yang terhubung ke sisi panas modul TEG. Pada bagian sisi dingin cold sink menggunakan alat penukar heatsink sirip. Konstruksi TEG menggunakan dua modul TEG yang disambungkan secara seri. Pengujian konstruksi TEG dilakukan pada sepeda motor automatic 110 cc fuel injection satu silinder empat langkah dengan 3 variasi kecepatan putaran mesin 1600, 2000 dan 3000 rpm dan waktu pengukuran mulai detik ke-O sampai detik ke-1500. Dari hasil pengujian didapatkan bahwa seiring kenaikan putaran mesin dan lamanya waktu pengukuran, maka suhu pada dinding knalpot, sisi panas, sisi dingin dan beda suhu (delta T) akan meningkat. Pada pengukuran detik ke-1500, pada putaran mesin 1600 rpm didapatkan beda suhu antara sisi panas dan sisi dingin TEG adalah $52^{\circ} \mathrm{C}$, tengangan sebesar $1770 \mathrm{mV}$ dan arus listrik sebesar $135 \mathrm{~mA}$. Pada putaran mesin $2000 \mathrm{rpm}$ didapatkan beda suhu $72^{\circ} \mathrm{C}$, tengangan sebesar $2625 \mathrm{mV}$ dan arus listrik sebesar $180 \mathrm{~mA}$. Dan pada putaran mesin 3000 rpm didapatkan beda suhu $74^{\circ} \mathrm{C}$, tengangan sebesar $2894 \mathrm{mV}$ dan arus listrik sebesar $205 \mathrm{~mA}$. Hasil penelitian ini diharapkan bisa diterapkan pada semua mesin pembakaran dalam, tidak hanya pada sepeda motor, tentunya dengan beberapa perubahan menyesuaikan dengan kondisi operasi mesin dan besarnya sumber panas dari mesin.
\end{abstract}

Kata kunci : thermoelektrik generator, heatsink, beda suhu, tegangan, arus listrik

\section{PENDAHULUAN}

Dalam beberapa tahun terakhir ini, pertumbuhan jumlah kendaraan bermotor di Indonesia terus meningkat. Dibandingkan dengan jenis kendaraan yang lain, jumlah pertumbuhan sepeda motor meningkat secara signifikan. Seiring dengan pertumbuhan jumlah kendaraan bermotor tersebut, maka tingkat konsumsi energi bahan bakar juga meningkat secara signifikan. Dari konsumsi bahan bakar pada sebuah mesin pembakaran dalam pada kendaraan bermotor, sebagian panas yang dihasilkan digunakan sebagai output kerja mekanik dan asesoris, sebagian lagi untuk pendinginan mesin dan kerugian gesekan, dan hampir $40 \%$ sisanya dibuang ke atmosfer sebagai gas panas buang melalui knalpot. Salah satu teknologi yang ramah lingkungan dan bisa mengubah panas gas buang menjadi energi listrik secara langsung adalah thermoelectrik generator (TEG).

Bagi pengendara sepeda motor, energi listrik tambahan yang bisa dihasilkan dari limbah panas buang akan sangat bermanfaat. Misalkan sebagai sumber energi alternatif pengganti lampu
LED, sebagai sistem charger hand phone, dan masih banyak yang lain.

Heatsink sebagai komponen utama alat penukar kalor pada sistem TEG memberikan pengaruh terhadap efektifitas perpindahan panas dan tentunya memberikan pengaruh langsung terhadap besarnya energi listrik yang akan dihasilkan. Optimasi penentuan geometri heatsink perlu dilakukan untuk mendapatkan biaya produksi yang optimal dan mendapatkan kinerja terbaik, sehingga dalam menentukan desainnya dilakukan penggambaran dengan menggunakan software CAD dan selanjutnya dilakukan pengujian secara eksperimental dari desain yang ada.

Dan dalam penelitian ini, penulis mencoba untuk melakukan studi eksperimen tentang pengaruh geometri heatsink pada sisi panas dan pada sisi dingin terhadap efektifitas perpindahan panas dan energi listrik yang dihasilkan. Hasil penelitian ini diharapkan dapat memberikan manfaat positif pada pengembangan pemanfaatan panas gas buang sepeda motor khususnya, dan kendaraan roda empat atau lebih serta mesin-mesin industri sebagai alternatif penghematan bahan bakar, mengurangi emisi gas buang dan pemanasan global dan tentunya 
meningkatkan efesiensi konsumsi bahan bakar pada mesin pembakaran dalam.

\section{TUJUAN PENELITIAN}

Tujuan penelitian ini adalah untuk menghasilkan sebuah konstruksi TEG yang bisa mengkonversi energi dari panas gas buang knalpot sepeda motor menjadi energi listrik dan melihat seberapa besar energi listrik yang bisa dibangkitkan pada variasi kecepatan putaran mesin.

\section{TINJAUAN PUSTAKA}

\subsection{Thermoelectric Generator (TEG)}

Thermoelectric generator (TEG) adalah sebuah perangkat yang mampu mengkonversi panas menjadi energi listrik secara langsung melalui fenomena yang disebut efek Seebeck. Perubahan energi panas menjadi energi listrik ini bisa dilakukan dengan cara menghubungkan sumber panas pada salah satu sisinya, namun pada sisi yang lain dijaga agar suhunya tetap rendah. Selanjutnya bila dua terminal keluaran diberikan beban listrik, maka arus listrik akan mengalir pada beban tersebut.

Struktur TEG adalah seperti ditunjukkan pada gambar 1, dimana modul termoelektrik dijepit oleh dua material penukar panas sisi panas dan sisi dingin pada masing-masing ujungnya.

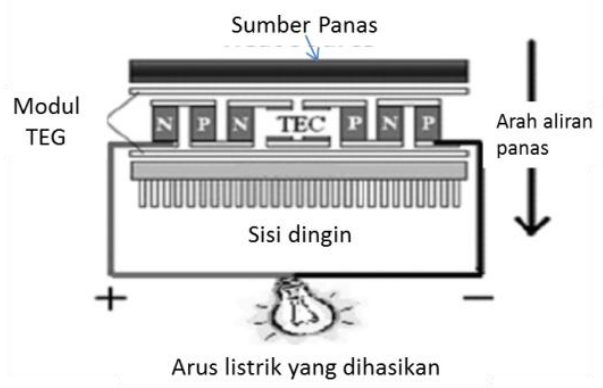

Gambar 1. Struktur Pembangkit Daya Termoelektrik

\subsubsection{Komponen thermoelectric generator}

Komponen utama dari kontruksi thermoelectrik generator (TEG) adalah sebagai berikut :

- $\quad$ Alat penukar kalor sisi panas (Hot Sink), alat penukar kalor untuk menyerap panas dari sumber
- Modul termoelektrik, merupakan media yang berfungsi untuk mengkonversi energi panas menjadi energi listrik. Pada aplikasinya material silikon germanium, telluride, atau bismuth telluride banyak digunakan.

- $\quad$ Alat penukar kalor sisi dingin (Cold Sink), digunakan untuk membantu meningkatkan pelepasan kalor pada sisi dingin sehingga meningkatkan efisiensi dari modul tersebut.

Potensi pembangkitan daya dari modul termoelektrik tunggal akan berbeda-beda bergantung pada ukuran, konstruksi dan perbedaan temperaturnya. Perbedaan temperatur yang makin besar antara sisi panas dan sisi dingin modul akan menghasilkan tegangan dan arus yang lebih besar.

\subsection{Dasar Perpindahan Panas}

Perpindahan panas ini berhubungan dangan laju perpindahan panas yang terjadi pada kondisi-kondisi tertentu dan penyebaran suhu dalam sebuah sistem. Proses terjadinya perpindahan panas dapat terjadi secara konduksi, konveksi, dan radiasi.

\section{A. Perpindahan Panas Konduksi}

Perpindahan panas secara konduksi adalah perpindahan panas yang terjadi pada suatu media padat, atau pada media fluida yang diam. Perpindahan Panas konduksi terjadi akibat adanya perbedaan temperatur antara permukaan yang satu dengan permukaan yang lain pada media tersebut.

Persamaan laju perpindahan panas konduksi biasa disebut dengan persamaan Hukum Fourier dituliskan sebagai berikut:

$$
\mathrm{Q}_{\mathrm{kond}}=\frac{k A \Delta T}{L}
$$

Dimana :

$\mathrm{Q}_{\text {kond }}=$ laju perpindahan panas $(\mathrm{W})$

$\mathrm{k}=$ konduktifitas termal $\left(\mathrm{W} / \mathrm{m}^{\circ} \mathrm{C}\right)$

$\mathrm{A}=$ luas penampang $\left(\mathrm{m}^{2}\right)$

$\mathrm{L}=\Delta \mathrm{x} \quad=$ ketebalan $(\mathrm{m})$

$\Delta \mathrm{T}=$ perbedaaan suhu $\left({ }^{\circ} \mathrm{C}\right)$

\section{B. Perpindahan Panas Konveksi}

Perpindahan panas konveksi merupakan proses perpindahan panas dengan kerja gabungan pada permukaan padat terhadap cairan atau gas yang bergerak Disebut konveksi paksa, jika fluida (cair atau gas) bergerak karena adanya gaya dari luar, sedangkan bila gerakan fluida yang terjadi disebabkan oleh perbedaan massa jenis maka perpindahan panas ini disebut konveksi alami. 
Laju perpindahan panas konveksi adalah:

$$
Q=h A(T s-\mathrm{T} \infty)
$$

Dimana :

$$
\begin{aligned}
& \mathrm{Q}=\text { laju perpindahan panas }(\mathrm{W}) \\
& \mathrm{h}=\text { koefisien perpindahan panas konveksi } \\
& \left(\mathrm{W} / \mathrm{m}^{2}{ }^{\circ} \mathrm{C}\right) \\
& \mathrm{A}=\text { luas penampang }\left(\mathrm{m}^{2}\right) \\
& \mathrm{Ts}=\text { perbedaan permukaan padat }(\mathrm{oC}) \\
& \mathrm{T} \infty=\text { perbedaan fluida }(\mathrm{oC})
\end{aligned}
$$

\section{Perpindahan Panas Radiasi}

Perpindahan panas radiasi adalah proses perpindahan panas dari satu media ke media lain akibat perbedaan temperatur tanpa memerlukan media perantara. Peristiwa radiasi akan lebih efektif terjadi pada ruang hampa, berbeda dari perpindahan panas konduksi dan konveksi yang mengharuskan adanya media perpindahan panas.

Persamaan laju perpindahan panas radiasi adalah :

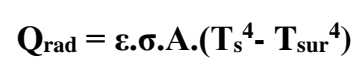

dimana :

$$
\begin{array}{ll}
\mathrm{Q}_{\mathrm{rad}}= & \text { laju perpindahan panas radiasi }(\mathrm{W}) \\
\varepsilon & =\text { emisivitas } \\
\sigma & =\text { Konstanta proporsionalitas, disebut juga } \\
& \text { konstanta Stefan Boltzmann.Dengan nilai } \\
& 5,67 \times 10-8(\mathrm{~W} / \mathrm{m} 2 \mathrm{~K}) \\
\text { Ts }= & \text { Temperatur benda }(\mathrm{K}) \\
\text { Tsur = } & \text { Temperatur lingkungan }(\mathrm{K}) \\
\mathrm{A} & =\text { luas permukaan perpindahan panas }\left(\mathrm{m}^{2}\right)
\end{array}
$$

Perpindahan panas pada sistem thermoelectrik generator terjadi secara konduksi dari pipa knalpot ke sisi hot sink, kemudian hot sink ke modul TEG dan dari sisi panas TEG ke cold sink, dan terakhir dari cold sink ke lingkungan secara konveksi.

Heat sink adalah perangkat yang meningkatkan disipasi panas dari permukaan yang panas, biasanya kasus komponen pembangkit panas, dengan ambient dingin, biasanya udara. Sebuah heat sink menurunkan hambatan ini dengan meningkatkan luas permukaan yang bersentuhan langsung dengan pendingin. Hal ini memungkinkan lebih banyak panas yang akan hilang danatau menurunkan suhu operasi perangkat . Tujuan utama dari heat sink adalah untuk menjaga suhu komponen bekerja di bawah suhu maksimum yang ditentukan oleh produsen perangkat .
Perpindahan panas dari heat sink ke lingkungan adalah dengan cara konveksi. Jika ada sirip-sirip di heat sink, efektifitas sirip harus besar untuk meningkatkan efisiensi dari heat sink. Persamaan untuk efektifitas sirip adalah sebagai berikut

$$
e_{f i n}=\frac{Q_{f i n}}{Q_{\text {nofm }}}=\frac{\sqrt{h p k A_{c}}\left(T_{b}-T_{\infty}\right)}{h A_{b}\left(T_{b}-T_{\infty}\right)}=\sqrt{\frac{k p}{h A_{c}}}
$$

Untuk meningkatkan efektifitas sirip (efin), konduktivitas termal (K) dan lingkar (p) sirip harus besar. Artinya sirip dirancang dirancang berdasarkan teori bahwa efektifitas sirip akan meningkat ketika konduktifitas thermal dan keliling sirip lebih besar daripada koefisien perpindahan panas konvektif (h) dan luas penampang ujung sirip (Ac).

Fluida pada sisi dingin TEG biasanya adalah udara, maka alat penukar kalor dengan sirip yang besar menjadi penting. Penggunaan dan pemilihan alat penukar kalor adalah hal yang sangat penting untuk keberhasilan sebuah desain TEG.

Pada sisi panas modul, alat penukar kalor (hot sink) bukan menjadi hal yang sangat kritikal. Sebagian besar modul temperature tinggi dapat beroperasi pada suhu mencapai $250^{\circ} \mathrm{C}$. Dan pada modul yang digunakan pada penelitian ini adalah $150^{\circ} \mathrm{C}$. Sedangkan suhu pada dinding knalpot bisa mencapai $240^{\circ} \mathrm{C}$. Sehingga ini memberikan keleluasaan kepada kita menggunakan perbedaan temperatur tinggi ini sebagai sebuah kemudahan desain. Meskipun alat penukar kalor ( hot sink) pada sisi panas ini kurang efesien, perbedaan temperature yang besar ini masih cukup untuk memenuhi kebutuhan suhu kerja pada sisi panas modul .

Alat penukar kalor pada sisi dingin (cold sink) harus lebih efesien. Bila Udara digunakan untuk mendinginkan sisi dingin dari modul, maka suhu terendah yang bisa dicapai adalah sebesar suhu lingkungan saat pengukuran. Karena power sebanding dengan perbedaan suhu kuadrat, maka sisi dingin harus dijaga agar suhunya serendah mungkin. Karena alasan inilah maka analisis alat penukar kalor pada sisi dingin penting untuk diperhatikan. 


\section{METODE PENELITIAN}

Metode penelitian yang digunakan dalam penelitian ini adalah dengan menggunakan metode eksperimen. Langkah pertama yang dilakukan adalah melakukan pengukuran suhu gas buang knalpot pada sepeda motor automatic $110 \mathrm{cc}$ untuk melihat potensi panas yang bisa dimanfaatkan. Selanjutnya melakukan perancangan desain alat penukar kalor pada sisi dingin dan sisi panas TEG dan kelengkapannya, serta melakukan proses produksi kontruksi TEG. Dan kemudian melakukan pengujian untuk mengetahui seberapa besar energi listrik yang bisa dihasilkan.

\subsection{Komponen Struktur TEG}

a. Heatsink sisi panas (Hot sink) : Komponen sistem perpindahan kalor pada sisi panas

- Material : Alumunium

- Desain : pada satu sisi yang bersinggungan dengan pipa knalpot adalah setengah lingkaran/ silinder dan pada sisi yang yang bersinggungan dengan modul TEG adalah berupa plat datar.

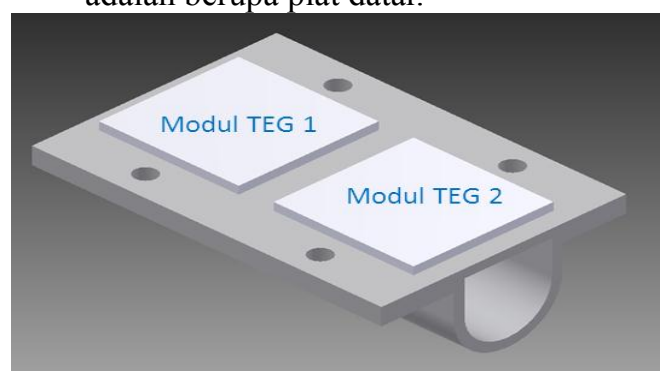

Gambar 2. Desain Hot Sink dan Modul

\section{b. Modul TEG}

Thermoelectrik tipe SP1848-27145 SA

Material: Ceramic / Bismuth Telluride

c. Heatsink sisi dingin (Cold Sink) : Komponen sistem perpindahan kalor pada sisi dingin

Material : Alumunium

Desain : Heatsink bersirip ekstrusi dan ada pemisah (slot)

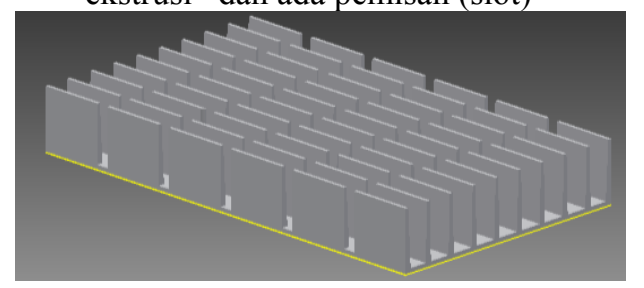

Gambar 3. Desain Heat sink sisi dingin (cold sink)

d. Komponen sambungan berupa mur dan baut yang berfungsi untuk mengaitkan beberapa komponen menjadi satu konstruksi TEG yang utuh.

e. Kendaraan Uji, Kendaraan yang digunakan sebagai objek penelitian sumber gas buang adalah jenis 1 unit sepeda motor Honda Beat jenis skutik $110 \mathrm{cc}$

\subsection{Konstruksi TEG}

Struktur TEG secara lengkap adalah seperti ditunjukkan pada gambar 4 berikut ini.

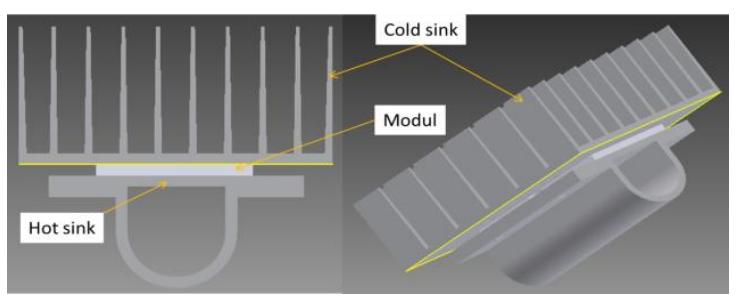

Gambar 4. Kontruksi TEG setelah semua komponen dipasangkan

Kontruksi lengkap TEG terdiri dari komponen hot sink ( bagian penjepit yang berbentuk setengah lingaran dan bidang datar yang merupakan komponen untuk menempatkan modul TEG pada sisi panas. Selanjutnya dibagian tengah ada 2 modul TEG yang disusun secara seri, dan terakhir pada bagian paling atas gambar adalah komponen cold sink.

Cold sink didesain untuk menjaga suhu pada sisi dingin serendah mungkin yaitu mendekati suhu lingkungan sekitar $35^{\circ} \mathrm{C}$. Sedangkan pada sisi panas suhunya didesain pada kisaran $150^{\circ} \mathrm{C}$ menyesuaikan dengan rentang kerja suhu dari modul TEG. Perpindahan panas dari sisi panas ke sisi dingin ada proses konduksi melalui modul TEG dan pembuangan panas untuk mencapai suhu ruang dibantu dengan komponen cold sink yang berlangsung secara konduksi dan konveksi.

Untuk memberikan luas permukaan untuk perpindahan panas yang besar, maka digunakan heatsink yang bersirip ekstrusi. Dan untuk memberikan ruang untuk udara dalam membantu proses pendinginan di sisi cold sink, maka pada sirip yang memanjang, dipotong sehingga membuat ada ruang pemisah $4 \mathrm{~mm}$. Sehingga sirip-sirip menjadi nampak berbentuk persegi dan ukurannya masingmsing per sirip adalah $20 \mathrm{~mm}$ × $2 \mathrm{~mm} \times 35 \mathrm{~mm}$ seperti ditunjukkan pada gambar 6. Desain Cold sink yang akan diujikan dalam penelitian ini adalah 
panjang $140 \mathrm{~mm}$, lebar sirip $65 \mathrm{~mm}$, tinggi dasar sirip $3 \mathrm{~mm}$ dan tinggi sirip $35 \mathrm{~mm}$.

\subsection{Prosedur Pengujian}

Prosedur pengujian yang dilakukan adalah sebagai berikut :

- Pengukuran suhu dilakukan pada tiga titik pengukuran dengan menggunakan thermokopel tipe $\mathrm{K}$ dan dipasangkan pada dinding pipa knalpot, sisi panas TEG dan sisi dingin TEG pada kondisi variasi putaran mesin idle ( 1600 rpm, $2000 \mathrm{rpm}$ dan $3000 \mathrm{rpm}$.

- Pada ujung positif modul TEG di sambungkan pada ujung positif mutimeter digital dan ujung negatif modul TEG disambungkan ke ujung negatif alat mutimeter digital untuk mengetahui besarnya arus dan tegangan yang dihasilkan dan pengujian dilakukan tanpa beban.

- Pelaksanaan pengujian ini adalah dengan kondisi sepeda motor tidak dijalankan, dan untuk mengurangi panas berlebih, selama pengujian ditambahkan kipas di depan pipa knalpot.

Struktur TEG yang dipasangkan pada sepeda motor ditunjukkan seperti pada gambar 5 berikut ini.

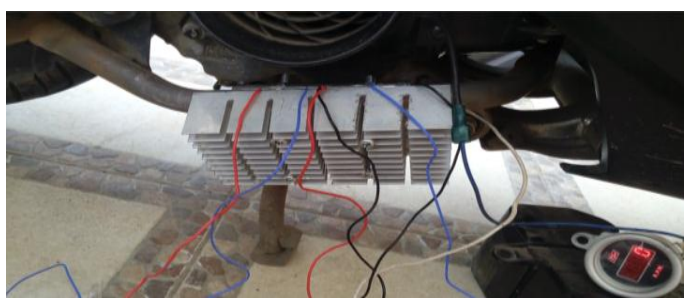

Gambar 5 Struktur TEG yang dipasang pada sepeda motor

Pengukuran suhu dilakukan pada tiga titik, yaitu pada dinding pipa knalpot, pada sisi panas TEG dan sisi dingin TEG dengan menggunakan thermokopel tipe $\mathrm{K}$, seperti ditunjukkan pada gambar 6.

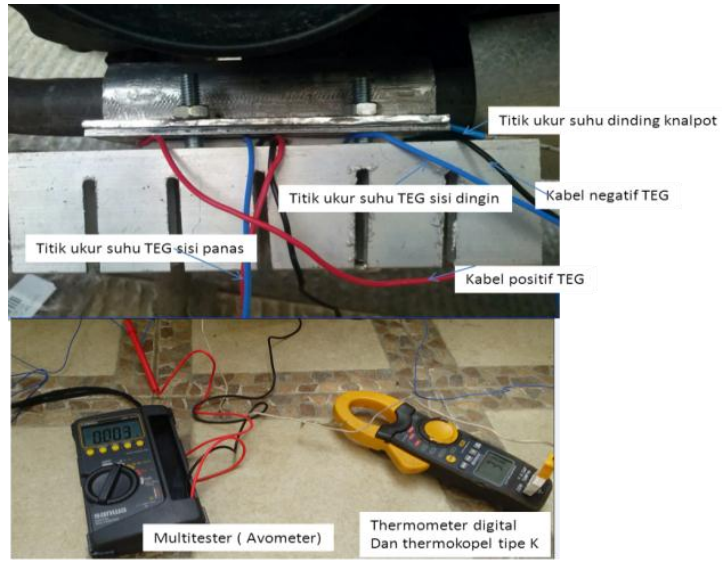

Gambar 6. Titik pengukuran suhu

\section{HASIL DAN PEMBAHASAN}

Pengujian dilakukan pada kondisi motor tidak dijalankan mulai dari putaran idle $1600 \mathrm{rpm}$, $2000 \mathrm{rpm}$ dan $3000 \mathrm{rpm}$ dan waktu pengukuran mulai dari detik ke-0 sampai sampai detik ke 1500 ( 25 menit).

Dari pengujian yang telah dilakukan bisa dilihat bagaimana pengaruh putaran mesin terhadap suhu pada knalpot, sisi panas dan sisi dingin TEG seperti ditunjukkan pada gambar 7, gambar 8 dan gambar 9 .

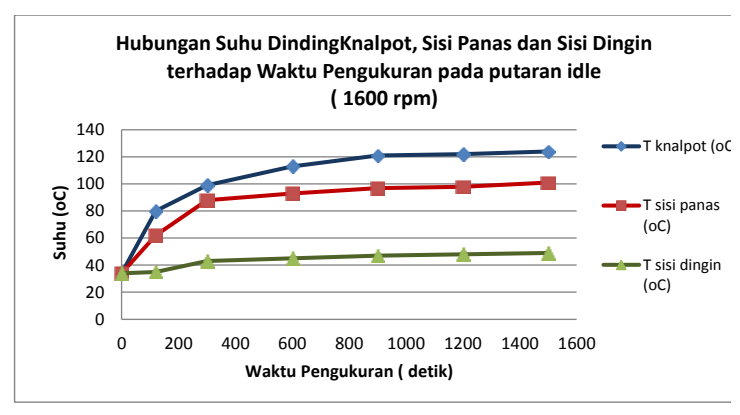

Gambar 7. Hasil pengukuran suhu pada struktur TEG pada kondisi putaran mesin 1600 rpm.

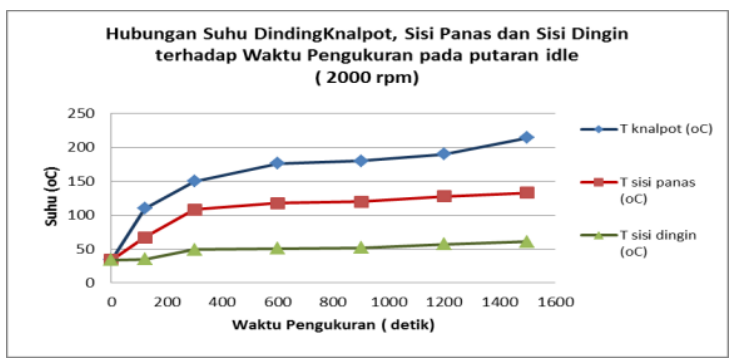

Gambar 8. Hasil pengukuran suhu pada struktur TEG pada kondisi putaran mesin 2000 rpm 


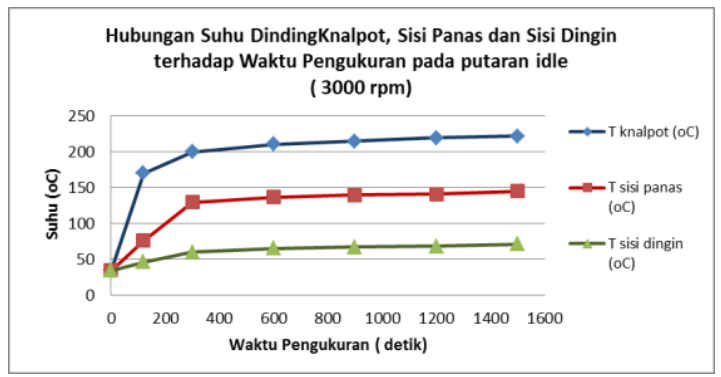

Gambar 9. Hasil pengukuran suhu pada struktur TEG pada kecepatan 3000 rpm

Dari gambar 10 ini terlihat bahwa seiring dengan kenaikan putaran mesin, maka beda suhu (Delta T) antara sisi panas dan sisi dingin akan meningkat. Dan ini yang diharapkan bahwa delta $\mathrm{T}$ ini akan semakin tinggi, sehingga bisa dihasilkan tegangan dan arus yang lebih besar.

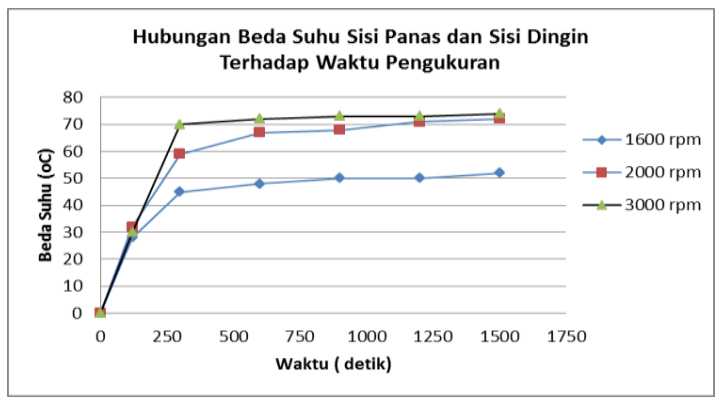

Gambar 10. Hubungan Beda Suhu (Delta T) Sisi Panas dan Sisi Dingin Terhadap Waktu Pengukuran

Sedangkan hubungan antara tegangan yang mampu dibangkitkan terhadap putaran mesin diperlihatkan pada gambar 11 .

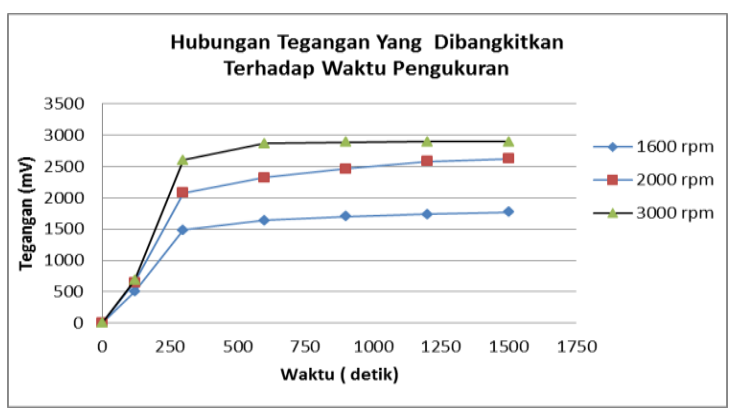

Gambar 11 Hubungan Tegangan Yang dibangkitkan terhadap Waktu Pengukuran

Hubungan antara arus listrik yang dibangkitkan terhadap putaran mesin pada waktu pengukuran diperlihatkan pada gambar 12 .

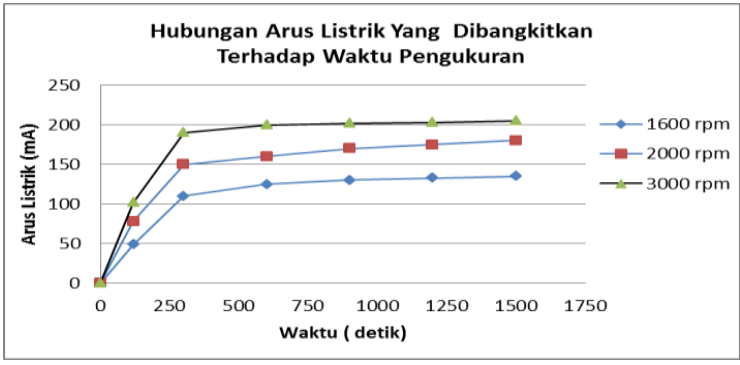

Gambar 12. Hubungan Arus Listrik Yang dibangkitkan terhadap Waktu Pengukuran

Dari gambar 7, 8 dan 9 terlihat bahwa suhu pada dinding knalpot sebagai sumber panas TEG akan naik seiring dengan putaran mesin. Sehingga suhu sisi panas TEG juga akan meningkat. Pada putaran $1600 \mathrm{rpm}$ suhu tertinggi pada sisi panas adalah $101^{\circ} \mathrm{C}$, sedangkan pada putaran $2000 \mathrm{rpm}$ $133^{\circ} \mathrm{C}$ dan pada putaran $3000 \mathrm{rpm}$, suhu pada sisi panas adalah $144^{\circ} \mathrm{C}$. Dari data ini menunjukkan bahwa alat penukar kalor dari dinding knalpot ke sisi panas TEG telah sesuai dengan rentang suhu yang ditetapkan oleh spesifikasi modul TEG, yaitu pada kisaran $150^{\circ} \mathrm{C}$. Sehingga bisa dikatakan bahwa alat penukar kalor pada sisi panas yang telah dirancang telah optimal.

Pada suhu pada sisi dingin, pada detik ke1500 dan pada putaran $1600 \mathrm{rpm}$ adalah sebesar $49^{\circ} \mathrm{C}$, pada putaran $2000 \mathrm{rpm}$ adalah $61^{\circ} \mathrm{C}$ dan pada putaran $3000 \mathrm{rpm}$ adalah $71^{\circ} \mathrm{C}$. Dan beda suhu (Delta T) antara sisi panas dan sisi dingin pada pada detik ke-1500 dan putaran $1600 \mathrm{rpm}$ adalah sebesar $52^{\circ} \mathrm{C}$, pada putaran $2000 \mathrm{rpm}$ adalah $72^{\circ} \mathrm{C}$ dan pada putaran $3000 \mathrm{rpm}$ adalah $74^{\circ} \mathrm{C}$. Pada putaran tinggi, suhu pada sisi dingin terus menunjukkan kenaikan. Walaupun peningkatannya tidak tajam dan beda suhu (Delta T) antara sisi panas dan sisi dingin juga semakin besar, namun ini alat penukar kalor pada sisi dingin ini masih bisa ditingkatkan kinerjannya sehingga bisa mendapatkan beda suhu (Delta T) yang lebih besar.

Dari gambar 16, 17, dan 18 terlihat bahwa nilai tegangan dan arus yang dibangkitkan meningkat seiiring dengan putaran mesin. Pada pengukuran detik ke 1500, pada putaran $1600 \mathrm{rpm}$ tegangan yang dihasilkan adalah $1770 \mathrm{mV}$, pada $2000 \mathrm{rpm}$ adalah 2625 dan pada $3000 \mathrm{rpm}$ dihasilkan tegangan $2894 \mathrm{mV}$. Sedangkan arus listrik yang dihasilkan pada $1600 \mathrm{rpm}$ adalah 135 $\mathrm{mV}$, pada $2000 \mathrm{rpm}$ adalah $180 \mathrm{mV}$ dan dan pada putaran $3000 \mathrm{rpm}$, arus yang dihasilkan adalah sebesar $205 \mathrm{~mA}$.

Hasil ini cukup bagus untuk penggunaan 2 modul TEG. Tegangan ini mungkin masih bisa dinaikkan jika proses pendinginan pada sisi dingin 
bisa lebih optimal. Dengan peningkatan kinerja alat penukar kalor pada sisi dingin, dan penambahan jumlah modul, diharapkan bisa meningkatkan besarnya tegangan yang mampu dibangkitkan oleh konstruk TEG.

\section{KESIMPULAN}

Berdasarkan hasil analisa dan pembahasan pada bab sebelumnya dapat disimpulkan sebagai berikut :

1. Konstruksi TEG yang telah dirancang dan dipasang pada sepeda motor bisa bekerja dengan baik dan bisa menghasilkan tegangan dan arus listrik sebagai sumber energi alternatif.

2. Dari hasil pengujian memperlihatkan bahwa suhu pada dinding knalpot, sisi panas dan sisi dingin modul TEG akan naik seiring dengan kenaikan putaran mesin dan lamanya waktu pengukuran.

3. Pada pengujian dengan waktu pengukuran detik ke-1500, pada putaran $1600 \mathrm{rpm}$ suhu pada sisi panas adalah $101^{\circ} \mathrm{C}$, sedangkan pada $2000 \mathrm{rpm}$ adalah $133^{\circ} \mathrm{C}$ dan pada putaran $3000 \mathrm{rpm}$, suhu pada sisi panas adalah $144^{\circ} \mathrm{C}$. Dari data ini menunjukkan bahwa alat penukar kalor dari dinding knalpot ke sisi panas TEG telah sesuai bekerja dengan optimal dan bisa mencapai rentang suhu kerja dari modul TEG yang digunakan.

4. Seiring dengan kenaikan delta $\mathrm{T}$ antara sisi panas dan sisi dingin, maka tegangan dan arus listrik yang dihasilkan akan meningkat. Pada pengukuran detik ke-1500, pada putaran mesin $1600 \mathrm{rpm}$ didapatkan beda suhu antara sisi panas dan sisi dingin $\mathrm{TEG}$ adalah $52^{\circ} \mathrm{C}$, tengangan sebesar $1770 \mathrm{mV}$ dan arus listrik sebesar 135 mA. Pada putaran mesin 2000 rpm didapatkan beda suhu $72^{\circ} \mathrm{C}$, tengangan sebesar $2625 \mathrm{mV}$ dan arus listrik sebesar $180 \mathrm{~mA}$. Dan pada putaran mesin $3000 \mathrm{rpm}$ didapatkan beda suhu $74^{\circ} \mathrm{C}$, tengangan sebesar $2894 \mathrm{mV}$ dan arus listrik sebesar $205 \mathrm{~mA}$.

5. Potensi energi dari panas knalpot sangat tinggi, karena suhu knalpot bisa mencapai lebih dari $230^{\circ} \mathrm{C}$. Dengan menggunakan teknologi TEG ini, energi dari panas buang bisa dikonversi menjadi energi listrik yang bisa digunakan untuk kebutuhan tambahan pengendara sepeda motor tanpa mengambil energi tambahan dari hasil proses pembakaran di mesin.

\section{DAFTAR PUSTAKA}

a. Q. Daniel, C. Perilhon, at all, Waste Heat Recovery applied to a tractor engine, International Conference on Technologies and Material for Renewable Energy, Environment and Sustainability, TMREES15

b. M.F Remelia, K.Verojporn, B.Singh, L. Kiatbodina , A.Date, A.Akbarzadeh, Passive Heat Recovery System using Combination of Heat Pipe and Thermoelectric Generator, The 7th International Conference on Applied Energy - ICAE2015

c. C. Ramesh Kumar *, Ankit Sonthalia, and Rahul Goel , Experimental Study On Waste Heat Recovery From An Internal Combustion Engine Using Thermoelectric Technology, Journal Thermal Science, Tahun 2011, Vol. 15, No. 4, hal. 10111022

d. Sugiyanto, Pemanfaatan Panas Knalpot Sepeda Motor Matic 110 Cc Untuk Pembangkitan Listrik Mandiri Dengan Generator Thermoelektrik, Diploma Teknik Mesin, Sekolah Vokasi, UGM

e. Sugiyanto, Rancang Bangung Konstruksi TEG (Thermoelectric Generator) Pada Knalpot Sepeda Motor Untuk Pembangkitan Listrik Mandiri, Diploma Teknik Mesin, Sekolah Vokasi, UGM

f. Olle Hogblom And Ronnie Andersson, Analysis of Thermoelectric Generator Performance by Use of Simulations and Experiments, Journal of ELECTRONIC MATERIALS, Vol. 43, No. 6, 2014, This article is published with open access at Springerlink.com

g. Ravi R.Nimbalkar, Sanket S. Kshirsagar, Thermoelectric Power Generation as an Alternative Green Technology of Energy Harvesting, International Journal of Advanced Computer Research (ISSN (print): 2249-7277 ISSN (online): 22777970), Volume-3 Number-3 Issue-11 September-2013

h. Eric M. Smith, Advances in Thermal Design of Heat Exchangers, John Wiley \& Sons Ltd., 2005

i. Jorge Vázquez, Miguel A. Sanz-Bobi, Rafael Palacios, Antonio Arenas, State of the Art of Thermoelectric Generators Based on Heat Recovered from the Exhaust Gases of Automobiles, Proceeding of 7th European Workshop on Thermoelectrics, Pamplona, Spain 
j. Yunus A. Cengel, Michael A. Boles, Thermodynamis : An Enginering Approach Six Edition, Mcgraw Hill Higher Education, 2007

k. Dan Mastbergen, Dr. Bryan Willson, Generating Light from Stoves using a Thermoelectric Generator, Engines and Energy Conversion Laboratory Department of Mechanical Engineering, Colorado State University 